\title{
Editorial
}

\section{Paediatric airway management problems; is there an anaesthetist in the house?}

The accompanying article by Fuller $e t$ al. highlights several challenging patient management issues in paediatric critical care. First, intensive care of infants and children is not limited to tertiary referral centres, but frequently originates within the community. The referring community itself may be within the same city or up to hundreds of miles away from the tertiary centre. Second, a clinical profile of the patients demonstrates that airway difficulties $(97 \%)$ constitute one of the major management problems in critically ill children. In particular, "upper airway obstruction" may be the presenting diagnosis in up to $46 \%$ of these children. Finally, only $26 \%$ of patients are likely to be managed by an anaesthetist prior to the arrival of a specialized transport team. Although the scope of the morbidity and mortality data were limited in the study, it is reasonable to speculate that the delayed management of upper airway obstruction could easily result in hypoxaemia and multisystem damage. Any unnecessary medical sequelae, either major or minor, may result in enormous financial costs to society for the normal adult life expectancy of that child.

It is not clear if paediatric patients are sicker than they were decades ago or if the ability to recognize and treat problems has improved. Although, in the area of neonatology, improvements in both medical management and mechanical technology have clearly resulted in increased survival of low birth weight infants who previously would have died. 'At the same time, critical care has expanded from being solely hospital-based to include the transport of sick children from anywhere within fueling distance of an aircraft. Most Provinces are attempting to centralize paediatric critical care into designated centres in order to control escalating costs while optimizing medical care. This has resulted in the formation of paediatric transport

From the University of Minnesota Hospital and Clinic, Department of Anesthesiology, 420 Delaware Street SE, Minneapolis, MN 55455. teams who regularly respond to paediatric management problems within the community. The volume and complexity of transport problems involving children appear to be increasing. A review of the Life Flight, Manitoba Air Ambulance service, demonstrates the scope of the problem. This service transports, by airplane, patients from communities that are beyond an 80-mile radius from the city of Winnipeg. The population of the Province of Manitoba is approximately one million and 450,000 live in communities outside the cily of Winnipeg. The longest transport distance is 625 miles and the average distance is 400 miles. In $1987,{ }^{2}$ the total number of combined neonatal and paediatric patients (up to 15 years of age) was 120 patients. Two years later, ${ }^{3}$ this volume of patients had increased $51 \%$ to 180 patients. The complexity of the patients can be assessed by the assignment of a priority code by the Air Ambulance Life Flight Team. There are four priority codes. Codes 4 and 3 are critical and emergency patients who require transport as soon as possible, preferably accompanied by both a physician and a Life Flight nurse. In 1989, codes 4 and 3 represented $81 \%$ of all paediatric patients transported and only $33 \%$ of adult patients! It is interesting to note that the 1989 Perinatal and Paediatric Report on Morbidity and Mortality ${ }^{4}$ presented to the Manitoba College of Physicians and Surgeons suggested that a reduction in morbidity and mortality for northem Manitoba was partly attributable to improved transport of critically ill paediatric patients.

In the accompanying article, none of the children who were managed by an anaesthetist required further respiratory care from the transport team. In contrast, $31 \%$ of the children in the study required immediate or urgent airway management. The question arises: where was the anaesthetist? While it is unreasonable to assume that anaesthetists will be physically available $24 \mathrm{hr}$ a day in all communities, the article documents that the anaesthetist's opinion was rarely sought even when the identified reason for transport was an airway problem.

I believe that it is time to reevaluate the role of 
anaesthetists in critical care medicine, in particular, paediatric intensive care. The general objectives for specialty training in anesthesia from the Royal College of Physicians and Surgeons of Canada" state "that the anaesthetist has an important role in both community and teaching hospitals as a specialist member of the health care team in surgery, intensive care, respiratory failure, resuscitation, management of pain and resuscitation of the neonate." In addition, the technical skills specifically include "competence in all procedures used in anaesthetic practice including airway management, cardiovascular resuscitation, patient monitoring and life support." Therefore, it would appear that the anaesthetist is the ideal physician to be involved in the delivery of critical care. Unfortunately, at a time when patient demands appear to be increasing, involvement by anaesthetists appears to be decreasing. Several features interact to reduce or eliminate the non-operating room commitments of the anaesthetist. In Manitoba, increased surgical workloads and anaesthetist manpower shortages ${ }^{6}$ have combined with economic and lifestyle pressures to reduce involvement in critical care units. On a national level, a recent study for the Canadian Society of Critical Care Medicine documented that only 13-18\% oi intensive care units had participation from anaesthetists. ${ }^{7}$ This is a sharp reduction from values as high as $60-70 \%$ in the 1970's and early 1980's.

It is interesting to speculate that by reducing our non-operating room activities, the specialty of anaesthesia is in danger of making itself invisible to our patients, our medical colleagues, and hospital administrators. Patients frequently spend a great deal of effort in choosing their surgeon, paediatrician, internist and general practitioner. In contrast, the anaesthetist is frequently assigned rather than chosen and the knowledge of the role of anaesthesia within the operating room can be summarized by patient questions such as "are you really a doctor?" At the same time, the distribution of limited resources by hospital administrators, governments and professional medical associations will be directed 10 groups who are articulate and visible. By not responding to patient needs, nor being actively involved in high profile activities outside the operating room, we are in danger of being left out of the development and delivery of health care in the 1990 's. I believe that the current "retreat" into the operating rooms will have a direct negative impact on the development and security of the specialty of anaesthesia.

It would be foolish to redirect all of our anaesthesia residency training towards paediatric intensive care. However, the areas of specialty training should reflect the needs of the community. At the present time, three months training in an adult intensive care unit is mandatory while acute care experience in paediatric/neonatal units is only recommended. Perhaps it is time to review that requirement and make a portion of paediatric intensive care mandatory. This decision does not presuppose that a rotation by anaesthesia residents through paediatric intensive care will generate paediatric intensivists. Hopefully this will expand their knowledge base and expose their skills to paediatricians and make them less anonymous.

In addition, there needs to be greater involvement in the development of the skills of paediatric transport teams by anaesthetists. The training, skills and knowledge required by these teams are direct extensions of daily anaesthetic practice. Finally, anaesthetists need to be more active in the continuous education of general practitioners and emergency room physicians who represent the primary physician contact for many patients.

I believe that direct involvement by anaesthetists in paediatric intensive care and transport is extremely beneficial in the delivery of paediatric critical care. Participation alone is both challenging and rewarding. At the same time it is an example of a high profile non-operating room activity that can result in the increased awareness of the skills and profile of anaesthetists within the hospital and the community. It is an opportunity waiting to be seized.

\section{Un enfant qui étouffe!... Mais où est donc l'anesthésiste?}

Dans leur article, Fuller et ses collègues soulignent plusieurs aspects importants des urgences pédiatriques. D'abord, ils nous enseignent qu'on ne peut restreindre les interventions lourdes aux seuls centres de troisième ligne puisqu'on doit souvent y avoir recours promptement et que l'enfant, même s'il peut être en détresse tout prês de l'hôpital pédiatrique, peut aussi fort bien en être éloigné de plusieurs centaines de kilomètres. Dans leur étude, le profil clinique des enfants dont l'état était critique comprenait habituellement ( $97 \%$ des cas) un sérieux problème de voies respiratoires. D'ailleurs, on diagnostiquait d'abord une obstruction des voies respiratoires supérieures dans $46 \%$ des cas. Enfin, les anesthésistes n'avaient été impliqués dans le traitement des enfants avant leur évacuation vers un centre spécialisé que dans $26 \%$ des cas. Même si la morbidité et la mortalité relevées dans l'étude étaient limitées, on peut présumer que tout retard dans le traitement d'une obstruction respiratoire 
haute peut entraîner une hypoxie aux conséquences désastreuses sur le plan financier et humain que la victime et ses proches devront supporter pendant longtemps.

Est-ce que les enfants sont plus malades aujourd'hui qu'il y trente ans ou est ce plutôt nos capacités de reconnaissance et de traitement des problèmes qui ce sont accrues? Il esı certain, du moins en néonatologie, que la mortalité des enfants de petit poids a fléchie devant l'amélioration de la technologie et des connaissances médicales.' Simultanément, les soins intensifs pédiatriques se sont étendus jusqu'aux confins du territoire par l'entremise de l'avion-ambulance. La plupart des provinces canadiennes ont regroupé leurs soins intensifs pédiatriques dans quelques centres spécialisés, histoire d'en optimiser la performance à un coût raisonnable. En corollaire, elles ont vu à la formation d'équipes spécialisées dans le transport d'enfants pour desservir leurs régions périphériques. Le nombre d'enfants qui font l'objet d'un transport et la complexité des cas semble toujours aller en grandissant. Le "Life flight", service d'avion-ambulance manitobain illustre bien la situation. Il s'adresse aux communautés situées au delà d'un rayon de $130 \mathrm{~km}$ de Winnipeg. Près de $45 \%$ du million de citoyens de la province vivent en dehors de sa capitale. Le transporteur parcourt $650 \mathrm{~km}$ en moyenne mais jusqu'à $1000 \mathrm{~km}$ à l'occasion et il s'est acquitté de 180 missions en $1989,{ }^{3}$ en hausse de $51 \%$ par rapport aux 120 de $1987^{2}$ (nouveauxnés et enfants de 15 ans et moins). L'équipe de transport évalue le degré d'urgence des problèmes et réserve les cotes trois et quatre aux cas urgents et critiques respectivement. Or en 1989, les cotes trois et quatre regroupaient $81 \%$ des cas de transport d'enfant mais seulement $39 \%$ des cas de transport d'adulte. Par ailleurs, l'édition 1989 du rapport du Collège des Médecins et des Chirurgiens du Manitoba sur la morbidité et la mortalité périnatale et pédiatrique, ${ }^{4}$ attribuait en partie la diminution de la morbidité et de la mortalité observée dans le nord de la province à la performance du système de transport des enfants malades.

On peut lire dans l'article de Fuller et coll., que l'équipe de transport dut intervenir chez $31 \%$ des enfants pour assurer la perméabilité de leurs voies respiratoires mais que de ce nombre, aucun n'avait été vu au préalable par un anesthésiste. Au delà de l'incapacité pour ce dernier d'être physiquement disponible $24 \mathrm{~h}$ par jour dans tous les hopitaux manitobains, il ressort clairement qu'on recherchait rarement son avis même lorsque la demande d'évacuation résultait d'un problème de voies respiratoires.

C'est là le signe qu'il faut réévaluer notre contribution aux soins de réanimation, particulièrement dans les soins intensifs pédiatriques. Les objectifs généraux des programmes de formation en anesthésie-réanimation tels qu'édictés par le Collège Royal des Médecins et des Chirurgiens du Canada ${ }^{5}$ spécifient que: «tant dans les hôpitaux généraux que dans les centres universitaires, l'anesthésiste joue un rôle important en tant que spécialiste participant aux activités chirurgicales, aux soins intensifs, aux réanimations d'adultes et de nouveaux-nés; il s'occupe aussi des problèmes de douleur et de défaillance respiratoire». De plus, l'anesthésiste doit maîtriser: " toutes les techniques essentielles à la pratique de l'anesthésie dont le contrôle des voies respiratoires, la réanimation cardiovasculaire, le monitorage et le soutien des fonctions vitales ". L'anesthésiste semble donc taillé sur mesure pour les soins de réanimation pourtant, alors que la demande se fait de plus en plus pressante, c'est un champ de pratique qu'il tend à délaisser. En fait, les anesthésistes semblent progressivement concentrer leurs activités au bloc opératoire. Au Manitoba, à tout le moins, une pénurie d'anesthésiste ${ }^{6}$ combinée à des pressions d'ordre économique et à la recherche d'une certaine qualité de vie convergent pour limiter l'implication de ces professionnels dans les unités de soins intensifs et au niveau pan-canadien, seulement 13 à $18 \%$ de ces dernières peuvent compter sur la participation d'un anesthésiste. ${ }^{7}$ On est loin des 60-70\% de participation des années ' 70 .

Malheureusement, j'estime que cette tendance tend à diminuer notre visibilité auprès de nos patients, de nos collègues médecins et des administrateurs hospitaliers. Les patients choisissent avec soin leur chirurgien, leur pédiatre, leur intemiste ou leur médecin de famille. Toutefois, lorsqu'ils se présentent au bloc opératoire, ils se voient trop souvent assigner un anesthésiste dont ils savent à peine s'il est un "vrai " docteur. En ces temps difficiles, les administrateurs hospitaliers et gouvernementaux, de même que les syndicats médicaux tendent à redéployer des ressources devenues rares au profit des groupes qui soignent leur image. En restant à couvert, en évitant de nous impliquer avec éclat en dehors des salles d'opération envers des patients qui en ont aussi besoin, nous risquons de manquer le bateau du développement des soins de santé d'ici au prochain millénaire. A n'en pas douter, notre repli actuel en salle d'opération sera néfaste pour le développement et la survie de notre spécialité.

II n'est évidemment pas question de détourner tout le programme de formation en anesthésie vers les soins intensifs pédiatriques. Pourtant, il faut s'adapter aux besoins du milieu. Nos programmes incluent trois mois de stages obligatoires en soins intensifs pour adultes et il y a peut-être lieu d'élargir cette obligation aux soins intensifs pédiatriques. Ce n'est pas en quelques semaines qu'on fera des intensivistes pédiatriques avec les résidents en anesthésie. Ils pourront toutefois élargir leurs connaissances et se frotter à des pédiatres, quitte à devenir moins anonyme. 
Par ailleurs, les équipes de transport pédiatriques ont beaucoup à apprendre des anesthésistes puisque les connaissances et les techniques utilisées sont souvent une extension de la pratique anesthésique quotidienne. Enfin, les anesthésistes doivent participer à la mise jour des connaissances des omnipraticiens et des urgentistes qui sont en première ligne.

J'estime que la réanimation de l'enfant profitera grandement d'une plus grande implication des anesthésistes dans les unités de soins intensifs pédiatriques et dans le transport des enfants malades. Relevons le défi de la participation. Entre autres gratifications, nous aurons le plaisir de montrer ce que nous savons faire à l'intérieur de notre hôpital et de notre communauté ; notre image s'en portera beaucoup mieux.

\section{References}

1 Tooley WH. Hyaline membrane disease. Telling it like it was. Am Rev Respir Dis 1977; 115: 19-28.

2 Annual Report, Life Flight Air Ambulance, Department of Health, Province of Manitoba. 1987.

3 Annual Report, Life Flight Air Ambulance, Department of Health, Province of Manitoba. 1989.

4 Lett D. Province's Pediatric Mortality Rate Drops. Winnipeg Free Press, April 6, 1990.

5 Specialty Training Requirements in Anesthesia, The Royal College of Physicians and Surgeons of Canada, 1989.

6 Anesthesia Manpower Report, Manitoba Medical Association, 1989.

7 Devitt JH, Pagliarello G, Simons J. The involvement of anaesthetists in critical care medicine. Can J Anaesth 1990; $\$ 119$. 